\title{
FRACTIONATION OF BENCE-JONES PROTEIN BY STARCH GEL ELECTROPHORESIS
}

\author{
BY \\ F. V. FLYNN AND ELIZABETH A. STOW \\ From the Department of Clinical Pathology, University College Hospital, London
}

(RECEIVED FOR PUBLICATION MARCH 20, 1958)

The development by Smithies (1955a) of starch gel as a medium for the electrophoresis of protein material marked an important advance, as it combines separation by electrical mobility with a form of pore filtration. Smithies (1955b) has been able to obtain 12 or more protein fractions from human serum with his one-dimensional technique and equally remarkable separation has been obtained with animal sera (Ashton, 1957 ; Latner and Zaki, 1957).

Applying this technique to the study of the abnormal proteins of multiple myeloma, BenceJones protein, which behaves as a single entity on paper electrophoresis, can often be resolved into two or more components in starch gel. There are a few reports in the literature of the occurrence of more than one abnormal electrophoretic fraction in the urine (Putnam and Stelos, 1953 ; Soulier, 1953; Wunderley and Caspani, 1954 ; ten Thije, 1956; Vis and Crokaert, 1956 ; Cummings, 1957 ; Gobert-Jones, 1957 ; Owen, 1957 ; Woodliff, Ainsworth, and Flemans, 1958). However, most electrophoretic studies have shown only a single abnormal protein, with or without albumin and normal serum globulins (Gutman, Moore, Gutman, McClellan, and Kabat, 1941 ; Moore, Kabat, and Gutman, 1943 ; Rundles, Cooper, and Willett, 1951; Slater and Kunkel, 1953 ; Osserman and Lawlor, 1955 ; Owen and Rider, 1957).

The findings on 13 urines from cases of multiple myeloma, eight of which showed the classical heat reactions of Bence-Jones protein, are reported here.

\section{Material and Methods}

Fresh urine specimens and samples of clotted blood were obtained from successive cases of multiple myeloma which satisfied all the accepted criteria for the diagnosis, including typical bone marrow biopsy findings. The urine was examined for the presence of Bence-Jones protein by the classical heat test at a controlled $p \mathrm{H}$ (Harrison, 1947), the urine being filtered at its boiling point and the filtrate examined carefully for the presence of any precipitate which appeared on cooling and dissolved on reheating. The total protein was estimated by a modified turbidometric method (Kingsbury, Clark, Williams, and Post, 1926), and all specimens, irrespective of the result of the heat test, were subjected to electrophoresis. Before electrophoretic analysis the protein was concentrated where necessary by dialysis of the urine at $4^{\circ} \mathrm{C}$. in "visking " tubing against a saturated solution of gum acacia ; the extent of the concentration depended on the initial protein content. Three batches, each of $200 \mathrm{ml}$. pooled normal urine, which contained no detectable protein by the usual qualitative tests and which were normal on microscopy, were treated similarly for control purposes.

Paper electrophoresis was carried out according to the qualitative technique of Flynn and de Mayo (1951) and starch gel electrophoresis as described by Smithies (1955b). The nomenclature used in conjunction with the latter method is that of Smithies (1955b). extended where necessary to describe bands with differing mobilities. For the purpose of assessing the mobilities of the fractions obtained in starch gels, further analyses were carried out in which the urines and their corresponding sera were run alongside one another in the same gel. In some cases this was done on paper also. To prove that Bence-Jones protein was in fact being fractionated in starch gel. the abnormal band obtained by paper electrophoresis was isolated and run in a gel.

\section{Results}

The results are summarized in the Table, and in Figs. 1 and 2 photographs of typical electrophoretic patterns are shown. With normal urines ill-defined patterns were obtained on paper electrophoresis, only albumin and $\gamma$ globulin being clearly discernible, but in starch gel prealbumins, albumin, post-albumins, and traces of $\beta$ and $\gamma$ globulins were demonstrated.

Interpretation of the electrophoretic analyses of the urines from the patients was complicated by the presence of some normal serum proteins. 
TABLE

DATA ON URINE AND SERUM PROTEINS FROM 13 CASES OF MULTIPLE MYELOMA

\begin{tabular}{|c|c|c|c|c|c|c|c|}
\hline \multirow{3}{*}{$\begin{array}{l}\text { Case } \\
\text { No. }\end{array}$} & \multicolumn{5}{|c|}{ Urine } & \multicolumn{2}{|c|}{ Serum } \\
\hline & \multirow{2}{*}{$\begin{array}{l}\text { Total Protein } \\
\text { (mg./100 ml.) }\end{array}$} & \multirow{2}{*}{$\begin{array}{c}\text { Result of } \\
\text { Heat Test for } \\
\text { Bence-Jones } \\
\text { Protein }\end{array}$} & \multirow{2}{*}{$\begin{array}{l}\text { Concentration } \\
\text { for } \\
\text { Electrophoresis }\end{array}$} & \multicolumn{2}{|c|}{$\begin{array}{l}\text { No. and Position of } \\
\text { Myeloma Protein(s) * }\end{array}$} & \multicolumn{2}{|c|}{$\begin{array}{l}\text { No. and Position of } \\
\text { Myeloma Protein(s) * }\end{array}$} \\
\hline & & & & $\begin{array}{c}\text { Paper } \\
\text { Electrophoresis }\end{array}$ & $\begin{array}{c}\text { Starch Gel } \\
\text { Electrophoresis }\end{array}$ & $\begin{array}{c}\text { Paper } \\
\text { Electrophoresis } \\
\end{array}$ & $\begin{array}{c}\text { Starch Gel } \\
\text { Electrophoresis }\end{array}$ \\
\hline $\begin{array}{l}1 \\
2 \\
3\end{array}$ & $\begin{array}{r}0 \\
<5 \\
100\end{array}$ & Positive & $\begin{array}{r}\times 550 \\
\times 250 \\
\times 30\end{array}$ & $\begin{array}{l}1-\gamma \\
1-\gamma \\
1-\gamma\end{array}$ & $\begin{array}{l}1, \text { slow } \gamma \\
1, \text { slow } \gamma \\
1, \text { slow } \gamma\end{array}$ & $\begin{array}{l}1, \mathbf{M} \\
1, \gamma \\
1, \gamma\end{array}$ & $\begin{array}{l}2, \text { both slow } a_{2} \\
1 \text {, fast } \gamma \\
1 \text {, fast } \gamma\end{array}$ \\
\hline 4 & 385 & , & $\times 10$ & $1-\gamma$ & $2\left\{\begin{array}{l}\operatorname{mid} \gamma \\
\text { fast } \gamma\end{array}\right.$ & 0 & $1, \operatorname{mid} \gamma$ \\
\hline 5 & 300 & Negative & $\times 17$ & $1-M$ & 4, all $\alpha \beta$ & $1, \mathbf{M}$ & 5, all $\alpha \beta$ \\
\hline 6 & 2,000 & Positive & $\times 1$ & $1-M$ & $3\left\{\begin{array}{l}\text { pre slow } a_{2} \\
\text { slow } a_{2} \\
\text { post slow } a_{2}\end{array}\right.$ & $1, \gamma$ & 1, fast $\gamma$ \\
\hline 7 & 500 & Negative & $\times 6$ & $1-M$ & $3\left\{\begin{array}{l}\beta \\
\text { post } \beta \\
\text { slow } \alpha_{2}\end{array}\right.$ & $1, \beta$ & $1, \alpha \beta$ \\
\hline 8 & 150 & - & $\times 20$ & 1-M & $3\left\{\begin{array}{l}\text { slow } \alpha_{2} \\
\text { post slow } \alpha_{2} \\
\text { post } \beta\end{array}\right.$ & $1, \gamma$ & 1, fast $\gamma$ \\
\hline 9 & 120 & Positive & $\times 30$ & $1-\beta$ & $2\left\{\begin{array}{l}\text { pre fast } \alpha_{2} \\
\text { fast } \alpha_{2}\end{array}\right.$ & $1, \gamma$ & 1 , fast $\gamma$ \\
\hline 10 & 500 & " & $\times 6$ & $1-\beta$ & $2\left\{\begin{array}{l}\text { fast } a_{2} \\
\beta\end{array}\right.$ & $1, \mathrm{M}$ & $3\left\{\begin{array}{l}2 \alpha \beta \\
\text { slow } \alpha_{2}\end{array}\right.$ \\
\hline 11 & 350 & ", & $\times 10$ & $1-\beta$ & $5\left\{\begin{array}{l}\text { pre fast } a_{2} \\
\text { fast } \alpha_{2} \\
2 \beta \\
\text { post } \beta\end{array}\right.$ & 0 & $-5+2$ \\
\hline 12 & 50 & $"$ & $\times 100$ & $1-\beta$ & $2\left\{\begin{array}{l}\text { fast } \alpha_{2} \\
\beta\end{array}\right.$ & $1, \gamma$ & 1, fast $\gamma$ \\
\hline 13 & 220 & ", & $\times 15$ & $1-\beta$ & $2\left\{\begin{array}{l}\text { fast } \alpha_{2} \\
\beta\end{array}\right.$ & 0 & 0 \\
\hline
\end{tabular}

* Abnormal proteins designated M occupy a position between $\beta$ and $\gamma$ bands (Gutman, Moore, Gutman, McClellan and Kabat, 1941).

These were often present in increased quantity and range as a result of the renal damage of the disease. In all the urines, except that of Case 5, these were present at much lower concentrations than the abnormal protein or proteins, and in four patients, Cases $6,10,11$, and 13, they were not detectable on paper at the concentration of urine examined. In the starch gels, where more material was analysed, traces of albumin and pre- and post-albumins were found in every case and, in some, traces of other fractions also. Recognition of the abnormal protein in the paper electrophoretic pattern presented no difficulty. In the starch gels the decision as to which bands represented Bence-Jones protein was made after considering their relative concentrations, whether they had any counterpart in the serum, and whether they corresponded to fractions found in normal urine. Thus, some Bence-Jones components had the same mobility as a fraction in the serum but could be recognized as abnormal by their density, and others migrated to positions where there was no serum counterpart. That this method of interpretation was reliable was confirmed by the experiments in which the BenceJones protein obtained on paper was isolated and run in a starch gel ; the bands obtained corresponded exactly with those attributed to BenceJones protein on analysis of the whole urine.

Comparison of the electrophoretic behaviour of the abnormal urine proteins on paper and starch gel shows that $\gamma$ proteins on paper usually correspond to slow $\gamma$ bands on starch, that $\beta$ BenceJones proteins on paper usually yield a $\beta$ and a fast $\alpha_{2}$ fraction, and $M$ bands (between $\beta$ and $\gamma$ ) usually yield several fractions with mobilities anywhere between the point of insertion and the $\beta$ position. The results of the corresponding serum analyses show that $\gamma$ myeloma globulins on paper invariably correspond to fast $\gamma$ bands on starch and that $M$ globulins usually correspond to slow $\alpha_{2}$ bands; the one $\beta$ myeloma globulin yielded a band in the $\alpha \beta$ position.

The results of the urine and serum analyses in a given patient show no correlation. In three patients, Cases 2, 3, and 5, the abnormal protein in the urine had the same mobility on paper as the abnormal serum globulin. In starch gel only one of these patients, Case 5, showed abnormal proteins of identical mobility in both, and in that case there was a general proteinuria with a urine pattern virtually identical with the serum. Case 4, 

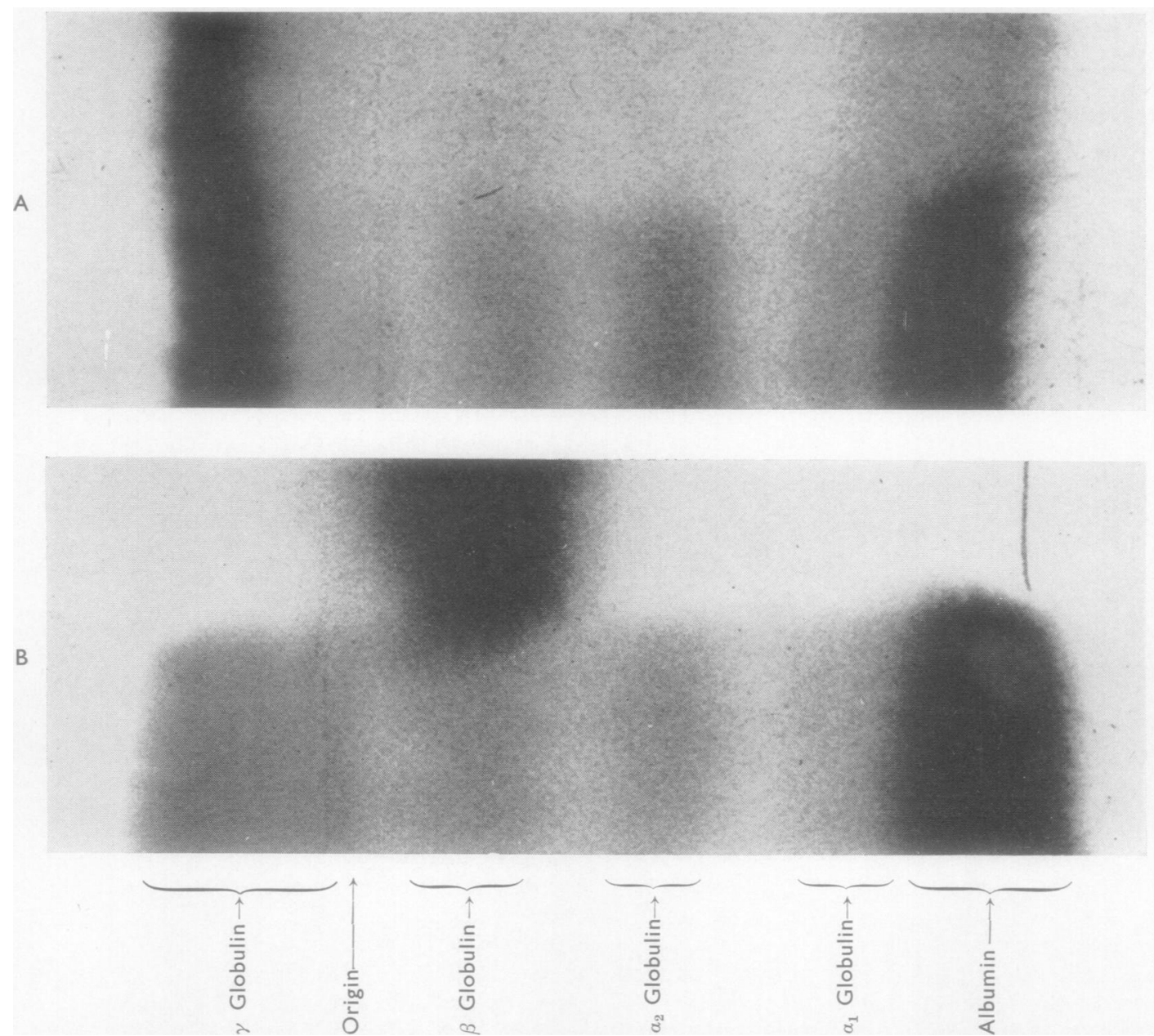

FIG. 1.-Electrophoresis of serum and urine proteins run alongside one another on paper. (A) Case 3 showing single Bence-Jones protein in urine, of same mobility as abnormal serum band, with some normal serum components. (B) Case 13 showing single Bence-Jones protein in urine.

however, had an abnormal band common to both serum and urine when run in starch, without evidence of a gross glomerular leak of protein. This case is also of interest because an abnormal serum band was detectable on the starch when not visible on paper.

\section{Discussion}

The above findings concerning the abnormal proteins found in both urine and serum provide further evidence of the complexity of the protein derangement in multiple myeloma.

The demonstration by the starch technique of normal serum components in the urine in all cases is of interest. It may partly explain why complete solution of the urine protein on boiling is so rarely observed, although it is established that on occasion there may be little or no solubility on $\stackrel{5}{\circ}$ boiling when virtually pure myeloma protein is in $N$ the urine (Osserman and Lawlor, 1955; Vis and Crokaert, 1956; Owen and Rider, 1957 : Flynn, unpublished observations).

The results with starch gel electrophoresis pro- $\stackrel{0}{\subset}$ vide abundant evidence of the heterogenicity of the abnormal urine protein excreted in myeloma, regardless of its behaviour in the heat test. Thus, 10 out of 13 urine proteins have been shown to consist of two or more components.

The improved resolution in starch gel as com- $\stackrel{\mathbb{Q}}{\complement}$ pared with paper is due to several factors. First and foremost there is the inherent property of the 8 method itself, combining electrophoresis with a 

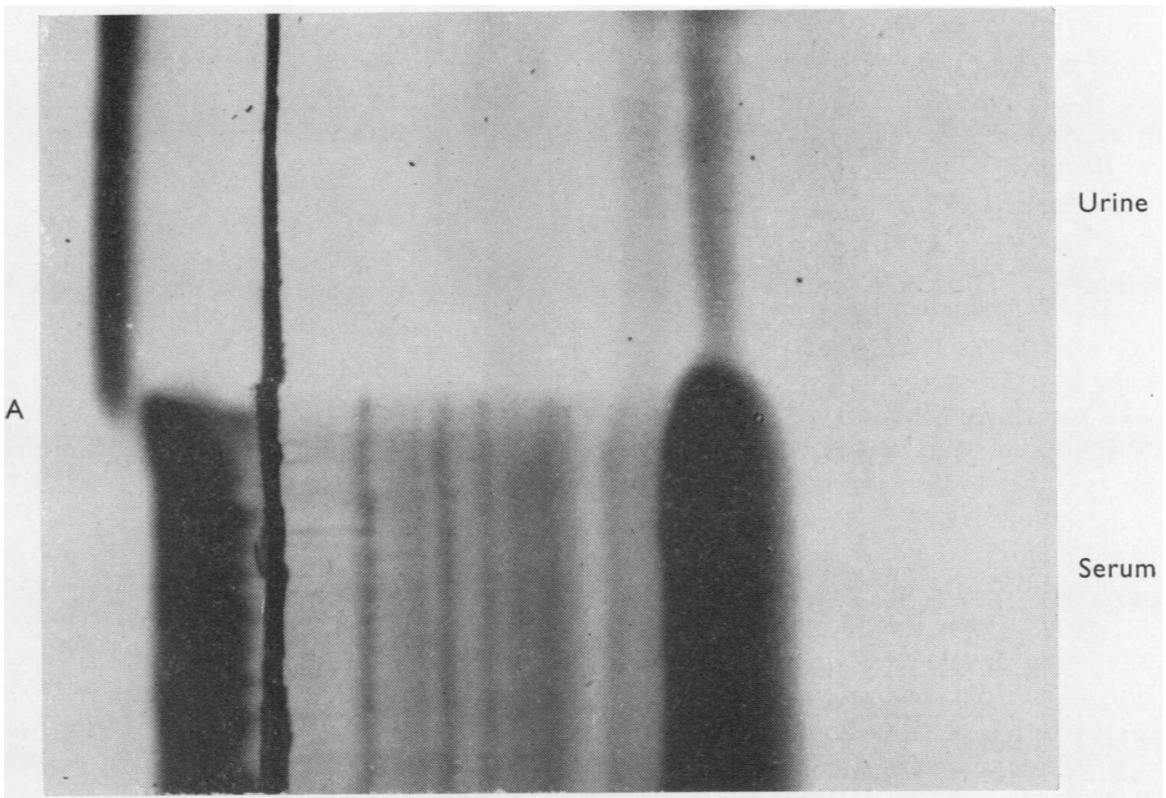

Serum

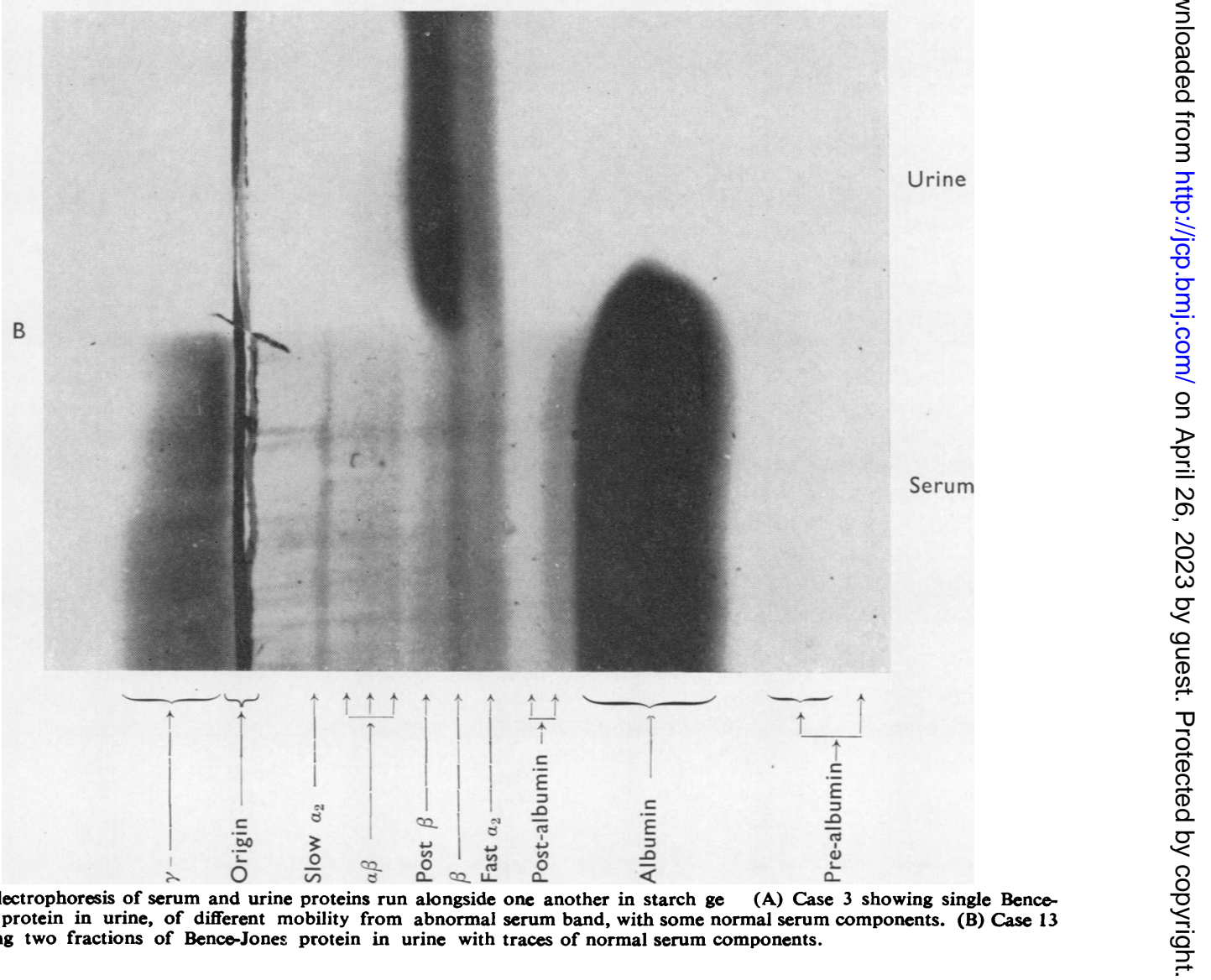

FIG. 2.-Electrophoresis of serum and urine proteins run alongside one another in starch ge (A) Case 3 showing single BenceJones protein in urine, of different mobility from abnormal serum band, with some normal serum components. (B) Case 13 showing two fractions of Bence-Jones protein in urine with traces of normal serum components. 
form of ultrafiltration, but also the larger sample and the compactness of the bands must play a part. The first of these factors seems to be the most important in the resolution of myeloma urine protein into several fractions. Thus the experiments showing fractionation of the BenceJones protein contained on a narrow segment of a paper electrophoretic strip prove that the starch method is not merely detecting components too small to show up distinctly on paper.

Other workers have occasionally found more than one peak on electrophoresis of Bence-Jones protein, as mentioned earlier, but usually only when the $p \mathrm{H}$ of the buffer was below the isoelectric point (Putnam and Stelos, 1953 ; ten Thije, 1956 ; Vis and Crokaert, 1956). Such a $p H$ effect is not the explanation of these results, as the $p \mathrm{H}$ was 8.6 in our paper runs and 8.2 for the starch analyses. Confirmatory evidence of the heterogenicity of individual Bence-Jones proteins exists in many related studies using salting out, the ultracentrifuge, or immunological methods (Putnam and Stelos, 1953 ; Awapara and Jirgensons, 1954 ; Wunderly and Caspani, 1954 ; Steyn-Parvé and ten Thije, 1955 ; Deutsch, 1955 ; Deutsch, Kratochvil, and Reif, 1955; ten Thije, 1956; Vis and Crokaert, 1956).

Characterization of myeloma urine protein according to its relative electrophoretic mobility in a starch gel is much more precise than on paper because of the compactness of the bands. Mobilities as such are influenced by the presence of other proteins, which may cause displacement when their concentration is high, but the technique of running serum and urine side by side enables correct identification by noting if a given band is continuous across the junction. An example of this method is shown in Fig. 1 (A) and Fig. 2 (A), where it can be seen that a $\gamma$ urine protein which appears identical with the abnormal $\gamma$ globulin in the serum, as judged by its mobility on paper, is distinct on starch. The results on starch gels support the view that the protein appearing in the urine is distinct from the myeloma protein in the serum, at least in the absence of a gross renal leak.

Starch gel has given results which show it to have considerable advantages over other media used for electrophoresis. The demonstration of an abnormal serum globulin in Case 4 , when none was detectable by the paper method, shows that this technique is of potential value in the diagnosis of multiple myeloma.

\section{Summary}

Serum and urine proteins from 13 cases of multiple myeloma have been examined by electrophoresis on paper and starch gel.

Starch gel electrophoresis has shown that in many patients the abnormal proteins are multiple. Three sera and 10 urines had more than one abnormal component, and apparently homogeneous Bence-Jones protein isolated by paper electrophoresis was shown to consist of several fractions when run in starch gel.

In starch gel abnormal proteins in urine rarely correspond with those in the serum, even when the two have the same mobility on paper.

Starch gel electrophoresis gives better resolution than paper electrophoresis and has potential value in the diagnosis of myeloma.

Work included here was done during the tenure by one of us (E. A. S.) of a grant from the research fund of University College Hospital. We wish to thank also Mr. A. Bligh and Mr. A. C. Lees for the photographs and the clinicians who have provided us with specimens.

\section{REFERENCES}

Ashton, G. C. (1957). Nature (Lond.), 179, 824.

Awapara, J., and Jirgensons, B. (1954). Tex. Rep. Biol. Med., 12, 799. Cummings, A. J. (1957). Lancet, 2, 598

Cummings, A. J. (1957). Lancet, 2, 598. . 97.

Kratochvil, C. H., and Reif, A. E. (1955). Ibid., 216, 103.

Flynn, F. V., and Mayo, P. de (1951). Lancet, 2, 235.

Gobert-Jones, J. A. (1957). Ibid., 2, 1068.

Gutman, A. B., Moore, D. H., Gutman, E. B., McClellan, V., and Kabat, E. A. (1941). J. clin. Invest., 20, 765.

Harrison, G. A. (1947). Chemical Methods in Clinical Medicine, 3rd od. J. \& A. Churchill, London.

Kingsbury, F. B., Clark, C. P., Williams, G., and Post, A. L. (1926). J. Lab. clin. Med., 11, 981 .

Latner, A. L., and Zaki, A. H. (1957). Nature (Lond.), 180, 1366.

Moore, D. H., Kabat, E. A., and Gutman, A. B. (1943). J. clin. Invest., 22, 67.

Osserman, E. F., and Lawtor, D. P. (1955). Amer. J. Med., 18, 462.

Owen, J. A. (1957). Lancet, 2, 1286.

Owen, J. A. (1957). Lancet, 2, 1286. . Path., 10, 373.

Putnam, F. W., and Stelos, P. (1953). J.biol. Chem., 203, 347.

Rundles, R. W., Cooper, G. R., and Willett, R. W. (1951). J. clin. Invest., $30,1125$.

Slater, R. J., and Kunkel, H. G. (1953). J. Lab. clin. Med., 41, 619.

Smithies, O.(1955a). Nature (Lond.), 175, 307.

(1955b). Biochem. J., 61, 629.

Soulier, J. P. (1953). Presse méd., 61, 49.

Steyn-Parvé, E. P., and Thije, O. J.ten (1955). Biochim. biophys. Acta, 16, 609.
Thije, O. J. ten (1956). Acta med. scand., 153, 253.

Thije, O. J. ten (1956). Acta med. scand., 153, 253.
Vis, H., and Crokaert, R. (1956). Acta clin. belg., 11, 455.

Woodlif, H. J., Ainsworth, R. W., and Flemans, R. J. (1958). Lancet, 1, 52.

Wunderly, C., and Caspani, R. (1954). Minerva med. (Torino), 45, 909. 